\title{
Dynamic changes of serum cholinesterase activity after severe trauma*
}

\author{
Li BA ${ }^{1}$, Ding-qian $\mathrm{WU}^{\dagger \dagger 1}$, An-yu QIAN $^{1}$, Mao ZHANG ${ }^{1}$, Bing XIONG ${ }^{2}$ \\ ( ${ }^{1}$ Department of Emergency Medicine, the Second Affiliated Hospital, School of Medicine, Zhejiang University, Hangzhou 310009, China) \\ $\left({ }^{2}\right.$ Department of Rehabilitation Medicine, the Second Affiliated Hospital, School of Medicine, Zhejiang University, Hangzhou 310052, China) \\ †E-mail: zjwdq0@163.com
}

Received May 5, 2014; Revision accepted Sept. 30, 2014; Crosschecked Nov. 13, 2014

\begin{abstract}
Objective: The aim of the present study was to examine dynamic changes in serum cholinesterase (ChE) activity during early-stage severe trauma and the clinical significance of these changes. Methods: This prospective, observational study included 81 patients with severe trauma who were treated between October 2011 and April 2013 in the emergency intensive care unit (EICU) of a university-affiliated, tertiary-care, grade A general hospital in China. Serum ChE activity was measured on Days 1, 3, and 7 post-injury. The correlation of dynamic changes in serum ChE activity with trauma severity and prognosis was assessed. Correlations between changes in serum ChE activity after injury and albumin (ALB), prealbumin (PAB), transferrin (TRF), and C-reactive protein (CRP) levels were also analyzed. Results: Serum ChE activity in trauma patients was $42.3 \%-50.2 \%$ lower on Days 1, 3, and 7 compared with the control $(P<0.001$ for all time points), and it continued to decrease after Day 7 in both the survival and death subgroups. In the subgroup with an injury severity score (ISS) of $\leq 25$, serum ChE activity initially decreased, but eventually increased. However, activity decreased continuously in the ISS $>25$ subgroup. ChE activity was significantly lower in both the death and the ISS $>25$ subgroups than in the survival and ISS $\leq 25$ subgroups on Days 1,3 , and 7 after injury. Activity was negatively correlated with ISS and acute physiology and chronic health evaluation III (APACHE III) at all time points. When comparing the receiver operating characteristic $(R O C)$ curves for predicting prognosis, the area under the curve (AUC) in the plot of serum ChE was similar to the AUCs in plots of ISS and APACHE III, but significantly smaller than the AUC in the plot of the trauma and injury severity score (TRISS). Serum ChE activity was positively correlated with ALB, PAB, and TRF at all time points post-injury. Activity was not significantly correlated with CRP on Day 1 , but was significantly and negatively correlated with CRP on Days 3 and 7 . Conclusions: There is a significant decrease in serum ChE activity after severe trauma. Serum ChE may be regarded as a negative acute phase protein (APP) and the dynamic changes in serum ChE may be useful as an auxiliary indicator for evaluating trauma severity and predicting prognosis.
\end{abstract}

Key words: Multiple trauma, Cholinesterase (ChE), Acute phase protein doi: 10.1631 jzus.B1400129

CLC number: R641

\section{Introduction}

¿ Corresponding author

* Project supported by the Zhejiang Medical and Health Research Project (No. 2012KYB092), the Education Department of Zhejiang Province (No. Y201018337), and the Science and Technology Department of Zhejiang Province (No. 2012C33124), China (iD) ORCID: Li BA, http://orcid.org/0000-0002-7987-5533; Ding-qian WU, http://orcid.org/0000-0003-3097-4503

(C) Zhejiang University and Springer-Verlag Berlin Heidelberg 2014
Severe trauma is a leading cause of death or disability among young and middle-aged populations in both developed and developing countries (Murdock, 2008; Nzegwu et al., 2008; Cowan et al., 2009). The number of trauma patients is increasing among older populations (Evans et al., 2010). Acute phase proteins (APPs) are plasma proteins that are synthesized in the liver. APPs induce, maintain, and regulate 
inflammation and the APP concentration increases or decreases by at least $25 \%$ in response to non-specific, post-traumatic inflammation. Common APPs include C-reactive protein (CRP), albumin (ALB), prealbumin (PAB), and transferrin (TRF) (Gabay and Kushner, 1999; Lo, 2006).

Serum cholinesterase (ChE), like APPs, is synthesized in the liver and secreted into the blood. ChE activity is lower than the normal in patients with organophosphate poisoning (Rehiman et al., 2008), chronic liver disease (Yoshiba et al., 2002), burns (Kamolz et al., 2002a; 2002b), cancer (Chougule et al., 2008), or serious infections (Kassab and Vijayakumar, 1995). The reduction in ChE activity is closely correlated with the severity of the condition and the prognosis. ChE activity decreases by variable degrees in patients with severe trauma, but to the best of our knowledge, no detailed study of ChE activity has been conducted in such patients. The goal of the present study was to analyze dynamic changes in serum ChE activity during early-stage severe trauma, to explore the correlations between ChE activity and condition severity, prognosis, and APP levels, and to elucidate the clinical significance of early changes in serum ChE activity after severe trauma.

\section{Subjects and methods}

\subsection{Subjects}

This was a prospective observational study and was approved by the Ethics Committee of the Second Affiliated Hospital, School of Medicine, Zhejiang University (Hangzhou, China). Because repeated venous blood tests are routine procedures in the intensive care unit (ICU) and the proteins (serum $\mathrm{ChE}$, ALB, PAB, TRF, and CRP) examined in this study are commonly measured in routine blood tests, no special informed consent was required from each patient or family. The tests did not cause additional suffering or medical expense.

Patients were treated in the emergency intensive care unit (EICU) of the Second Affiliated Hospital, School of Medicine, Zhejiang University (Hangzhou, China) between October 2011 and April 2013. Inclusion criteria for patients were: admission to the EICU within $24 \mathrm{~h}$ of injury, an injury severity score (ISS) greater than 16, and more than 18 years of age. Ex- clusion criteria for patients were: chronic liver disease, organophosphorus exposure, active tuberculosis or malignancy, a history of infection prior to the injury, or prior liver damage.

The inclusion criterion for the control group was: more than 18 years of age. Exclusion criteria for the control group were: liver disease, organophosphorus exposure, tuberculosis, malignancy, or various chronic or acute infections.

\subsection{Sample collection and blood tests}

Fasting venous blood samples were collected from all included patients at 6:00 am on Days 1,3, and 7 post-injury, and stored in tubes without anticoagulant (BD Co., USA). Within $30 \mathrm{~min}$ of collection, the blood samples were centrifuged (1000 r/min, $10 \mathrm{~min})$ at room temperature. The serum was then collected and the levels of ChE, ALB, PAB, TRF, and CRP were measured. The serum ChE activity was measured using the DTNB (5,5'-dithiobis(2-nitrobenzoic acid)) chromogenic velocity method and an Olympus 2700 automatic biochemical analyzer (Olympus, Japan; normal reference range 203-460 U/L). ALB was measured using the BCG (bromocresol green) method and the same analyzer (normal reference 3.5-5.0 g/dl). $\mathrm{PAB}$ and TRF were measured by rate nephelometry using a Beckman-Coulter special protein analyzer (Beckman-Coulter Co., USA; normal reference range for PAB 180-450 mg/L; normal reference range for TRF 2.1-3.6 g/L). CRP was measured by transmission turbidimetry using the OLYMPUS 2700 automatic biochemical analyzer (normal reference range $<8.00 \mathrm{mg} / \mathrm{L}$ ). Fasting venous blood samples were collected from control subjects early in the morning and serum $\mathrm{ChE}$ activity was tested as above.

\subsection{Data processing}

Dynamic changes in serum ChE activity after injury were examined in the patient group and compared with those in the control group. Patients were divided into survival and death subgroups based on prognosis, and into ISS $\leq 25$ and ISS $>25$ subgroups. Dynamic changes in serum $\mathrm{ChE}$ activity were analyzed in each subgroup and compared between the different subgroups. Correlations between serum $\mathrm{ChE}$ activity and ISS, and serum ChE activity and acute physiology and chronic health evaluation III (APACHE III) were examined on Days 1, 3, and 7. 
Receiver operating characteristic (ROC) curves were generated to give area under the curve (AUC) values to predict the prognosis. Curves were plotted for post-trauma serum ChE level, ISS, trauma and injury severity score (TRISS), and APACHE III. The curves were compared and optimal serum $\mathrm{ChE}$ thresholds for predicting the prognosis at different time points were obtained. Dynamic changes in ALB, PAB, TRF, and CRP were measured and the correlations between these and serum ChE activity were analyzed in the severe trauma patients.

\subsection{Statistical analysis}

Quantitative data are expressed as mean \pm standard deviation (SD). SPSS 19.0 (IBM, USA) and MedCalc V12.7.7.0 (MedCalc Software Bvba, Belgium) were used for statistical analysis. A two-sample $t$-test or Mann-Whitney rank sum test was performed for comparison of the means between two groups. A $\chi^{2}$-test was performed for comparison of rates and Pearson correlation analysis was used for correlation analysis. Dynamic changes in the mean within groups were compared using univariate repeated measures analysis of variance (ANOVA) and pair-wise comparisons were performed using the Tukey's test. A $Z$-test was used for comparisons of the AUCs of ROC curves. $P<0.05$ was considered statistically significant.

\section{Results}

\subsection{Included subjects}

Eighty-one subjects meeting the selection criteria were selected from a total of 654 trauma patients. All patients were provided with active life support for organ function and special treatments (such as surgery, hemodialysis, or mechanical ventilation) were implemented based on their conditions. Seventy-six healthy subjects, who received physical exams in the same hospital during the same period of time, were included in the control group. Basic clinical information for all included subjects is shown in Table 1 .

\subsection{Dynamic changes in serum ChE activity in severe trauma patients and subgroups after injury}

The serum ChE activity was significantly lower on Days 1, 3, and 7 post-injury in the trauma patient group ((181.8 \pm 45.7$), \quad(166.4 \pm 76.3)$, and (156.9 \pm 63.9) U/L, respectively) compared with the control group ((315.0 \pm 55.0$) \mathrm{U} / \mathrm{L} ; P<0.001$ for all time points). In addition, serum ChE activity decreased continuously from Day 1 to Day 7 ( $F=16.346, P<0.001$; Fig. 1). Activity had decreased by $42.3 \%, 47.2 \%$, and $50.2 \%$ on Days 1,3 , and 7 , respectively, in the patient group compared with the control group.

Table 1 Basic clinical information of included subjects

\begin{tabular}{|c|c|c|c|c|}
\hline Clinical characteristics & Patient group $^{*}$ & Control group $^{*}$ & Statistics & $P$ value \\
\hline \multicolumn{5}{|l|}{ Sex } \\
\hline Male & $57(70.4 \%)$ & $53(69.7 \%)$ & \multirow{2}{*}{$\chi^{2}=0.008$} & \multirow{2}{*}{0.931} \\
\hline Female & $24(29.6 \%)$ & $23(30.3 \%)$ & & \\
\hline Age (year) & $46 \pm 18(21-87)$ & $44 \pm 16(21-76)$ & $t=0.804$ & 0.422 \\
\hline \multicolumn{5}{|l|}{ Cause of injury } \\
\hline Traffic accident & 51 & & & \\
\hline Fall & 19 & & & \\
\hline Compression by heavy objects & 6 & & & \\
\hline Explosion & 2 & & & \\
\hline Chopped or stabbed by sharp objects & 3 & & & \\
\hline Number of injury sites & $2.8 \pm 0.9$ & & & \\
\hline Injury severity score (ISS) & $34.0 \pm 11.9(19-61)$ & & & \\
\hline ISS $\leq 25$ & 28 & & & \\
\hline ISS $>25$ & 53 & & & \\
\hline \multicolumn{5}{|l|}{ Outcome } \\
\hline Death & 25 & & & \\
\hline Survival & 56 & & & \\
\hline
\end{tabular}

* Data are expressed as number of cases (percentage) or mean \pm SD (range) 


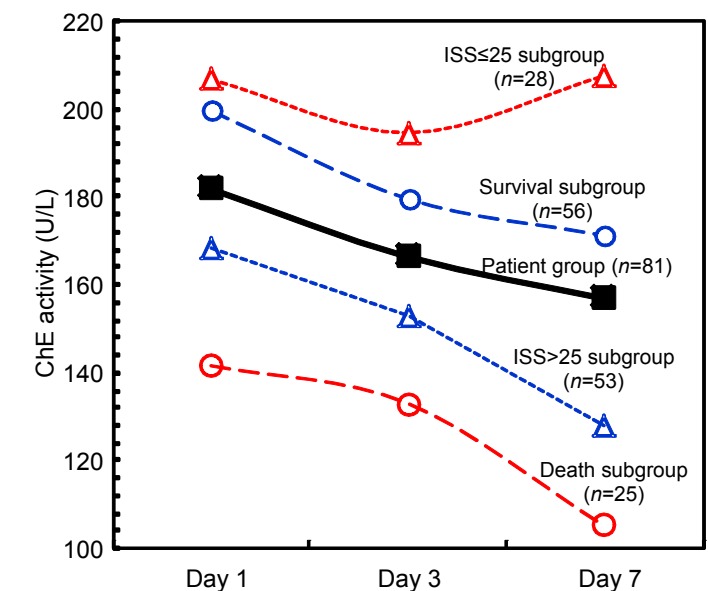

\begin{tabular}{|c|c|c|c|c|c|c|}
\hline \multirow{2}{*}{$\begin{array}{l}\text { Patient } \\
\text { group }\end{array}$} & \multicolumn{2}{|c|}{ Day 1 vs. Day 3} & \multicolumn{2}{|c|}{ Day 1 vs. Day 7} & \multicolumn{2}{|c|}{ Day 3 vs. Day 7} \\
\hline & $q$ & $P$ & $q$ & $P$ & $q$ & $P$ \\
\hline \multicolumn{7}{|c|}{ Subdivided according to prognosis } \\
\hline Survival & 4.687 & 0.004 & 6.276 & $<0.001$ & 1.653 & 0.475 \\
\hline Death & 2.659 & 0.160 & 5.893 & $<0.001$ & 3.455 & 0.051 \\
\hline \multicolumn{7}{|c|}{ Subdivided according to injury severity } \\
\hline ISS $\leq 25$ & 5.622 & $<0.001$ & 2.454 & 0.203 & 3.011 & 0.095 \\
\hline ISS $>25$ & 3.514 & 0.039 & 8.120 & $<0.001$ & 4.848 & 0.003 \\
\hline All & 15.304 & 0.004 & 24.869 & $<0.001$ & 9.565 & 0.129 \\
\hline
\end{tabular}

Comparison of serum $\mathrm{ChE}$ activity between the survival and death subgroups on Day 1: $T=611.000, P<0.001$; Day 3: $T=-2.924, P=0.005$; Day 7: $T=226.000, P<0.001$. Comparison of serum ChE activity between the ISS $\leq 25$ and ISS $>25$ subgroups on Day 1: $T=2.581, P=0.012$; Day 3: $T=1302.000$, $P<0.001$; Day 7: $T=1283.000, P<0.001$

Fig. 1 Dynamic changes of the serum ChE activity in severe trauma patients and subgroups for $7 \mathrm{~d}$ after injury

Serum ChE activities were (199.7 \pm 49.1$)$, (179.6 \pm 70.9$)$, and $(171.3 \pm 65.1) \mathrm{U} / \mathrm{L}$ in the survival subgroup and (141.6 \pm 32.2$),(133.0 \pm 46.6)$, and $(105.1 \pm 19.3) \mathrm{U} / \mathrm{L}$ in the death subgroup on Days 1,3, and 7 , respectively. Serum ChE activity decreased continuously in both subgroups for the entire $7 \mathrm{~d}$ post-injury (survival subgroup $F=10.683, P<0.001$; death subgroup $F=8.686, P<0.001$ ). In addition, serum ChE activities on Days 1, 3, and 7 post-injury were significantly lower in the death subgroup than in the survival subgroup (Fig. 1).

Serum ChE activities were (206.8 \pm 46.3$)$, (194.7 \pm 69.2$)$, and $(207.7 \pm 59.0) \mathrm{U} / \mathrm{L}$ in the $\mathrm{ISS} \leq 25$ subgroup and (168.5 \pm 49.9$),(153.1 \pm 63.6)$, and $(128.0 \pm 56.4) \mathrm{U} / \mathrm{L}$ in the ISS $>25$ subgroup on Days 1 , 3 , and 7 , respectively. Activity was significantly lower on Day 3 than on Day 1 in the ISS $\leq 25$ subgroup, but it had risen again by Day $7(F=7.945, P=0.001)$. Serum $\mathrm{ChE}$ activity decreased continuously throughout the entire $7 \mathrm{~d}$ post-injury in the ISS $>25$ subgroup
$(F=16.506, P<0.001)$. Serum $\mathrm{ChE}$ activity was significantly lower in the ISS $>25$ subgroup than in the ISS $\leq 25$ subgroup on Days 1, 3, and 7 (Fig. 1).

3.3 Correlation between dynamic changes in serum ChE activity in trauma patients and the severity of the patient's condition

Post-injury, APACHE III was $54.1 \pm 38.9$ (range 6-146), 48.8 \pm 38.7 (range 8-136), and 43.2 \pm 39.3 (range 5-144) on Days 1, 3, and 7 in the trauma patient group, respectively. Serum $\mathrm{ChE}$ activity was significantly and negatively correlated with APACHE III and with ISS on Days 1, 3, and 7 (Fig. 2).

\subsection{Predicting prognosis based on serum $\mathrm{ChE}$ activity in severe trauma patients}

Patient death was defined as 1 . ROC curves for predicting prognosis were plotted using the ISS and TRISS of the patients after injury, and the APACHE III and serum ChE activities on Days 1, 3, and 7 (Fig. 3). At all time points after injury, the AUC of the ROC curve plotted using serum ChE was not significantly different from that of the curve plotted using ISS (Day 1: $Z=0.751, P=0.453$; Day 3: $Z=1.157$, $P=0.247$; Day 7: $Z=0.439, P=0.661)$. However, it was significantly smaller than the AUC of the curve plotted using TRISS (Day 1: $Z=3.176, P=0.001$; Day 3: $Z=3.292, P=0.001$; Day $7: Z=2.822, P=0.005)$. The AUCs of ROC curves plotted using serum ChE were not significantly different from those plotted using APACHE III on Days 1 and 7 (Day 1: $Z=1.565$, $P=0.118$; Day 7: $Z=1.294, P=0.196)$. However, the AUC of the ROC curve plotted using serum $\mathrm{ChE}$ was significantly smaller on Day 3 than that of the curve plotted using APACHE III $(Z=2.710, P=0.007)$.

The largest cut-off point of Youden's index (sensitivity+specificity-1) was regarded as the optimal threshold. The optimal thresholds determined for serum $\mathrm{ChE}$ for predicting prognosis were 197.0, 152.5, and $120.0 \mathrm{U} / \mathrm{L}$ on Days 1, 3, and 7 after injury, respectively (Table 2). There was no significant difference in prognosis prediction between any of the time points when doing pair-wise comparisons of the AUCs of ROC curves plotted using serum $\mathrm{ChE}$ (Day 1 vs. Day 3: $Z=0.456, P=0.648$; Day 3 vs. Day 7: $Z=0.936, P=0.349$; Day 1 vs. Day $7: Z=0.578$, $P=0.563)$. 

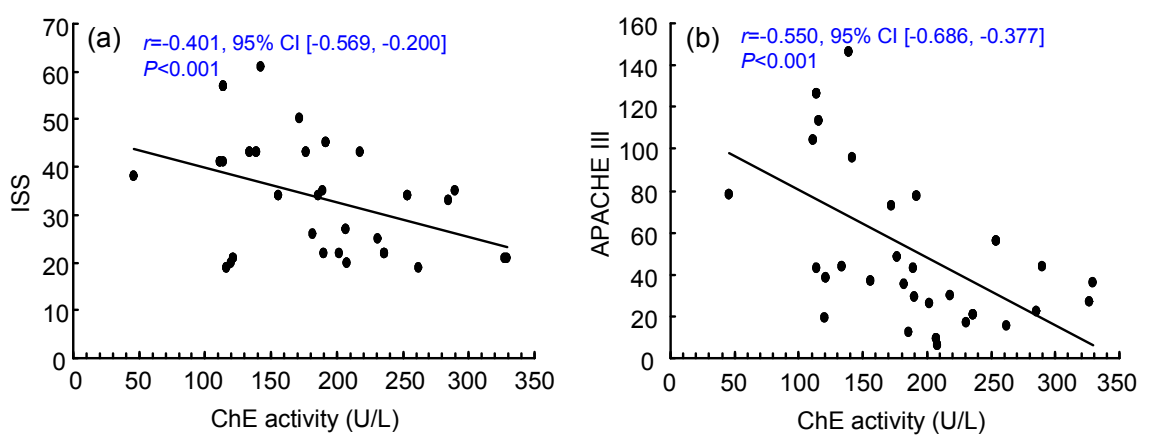

Fig. 2 Correlation analysis of serum ChE activity with ISS and APACHE III in severe trauma patients
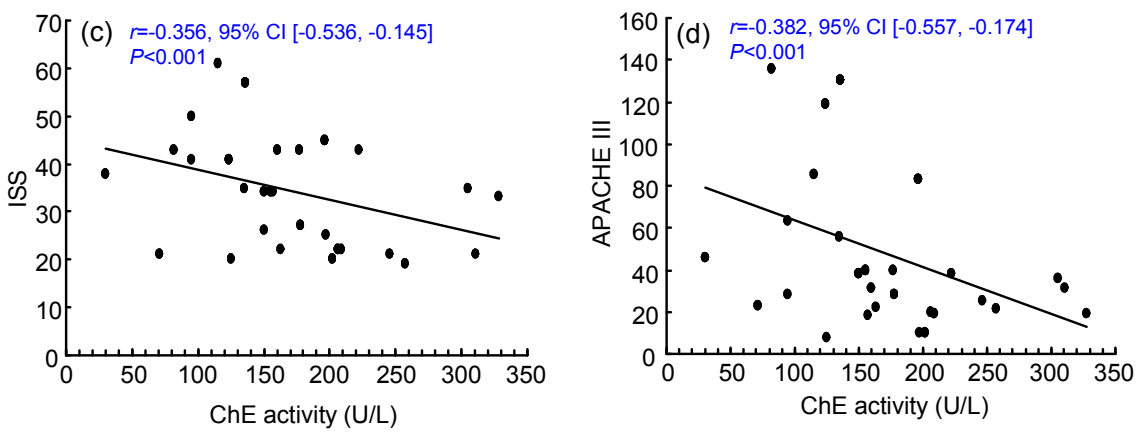
after injury $(n=81)$

(a, c, e) Serum ChE activity vs. ISS on Days 1, 3, and 7, respectively; (b, d, f) Serum ChE activity vs. APACHE III on Days 1, 3, and 7, respectively
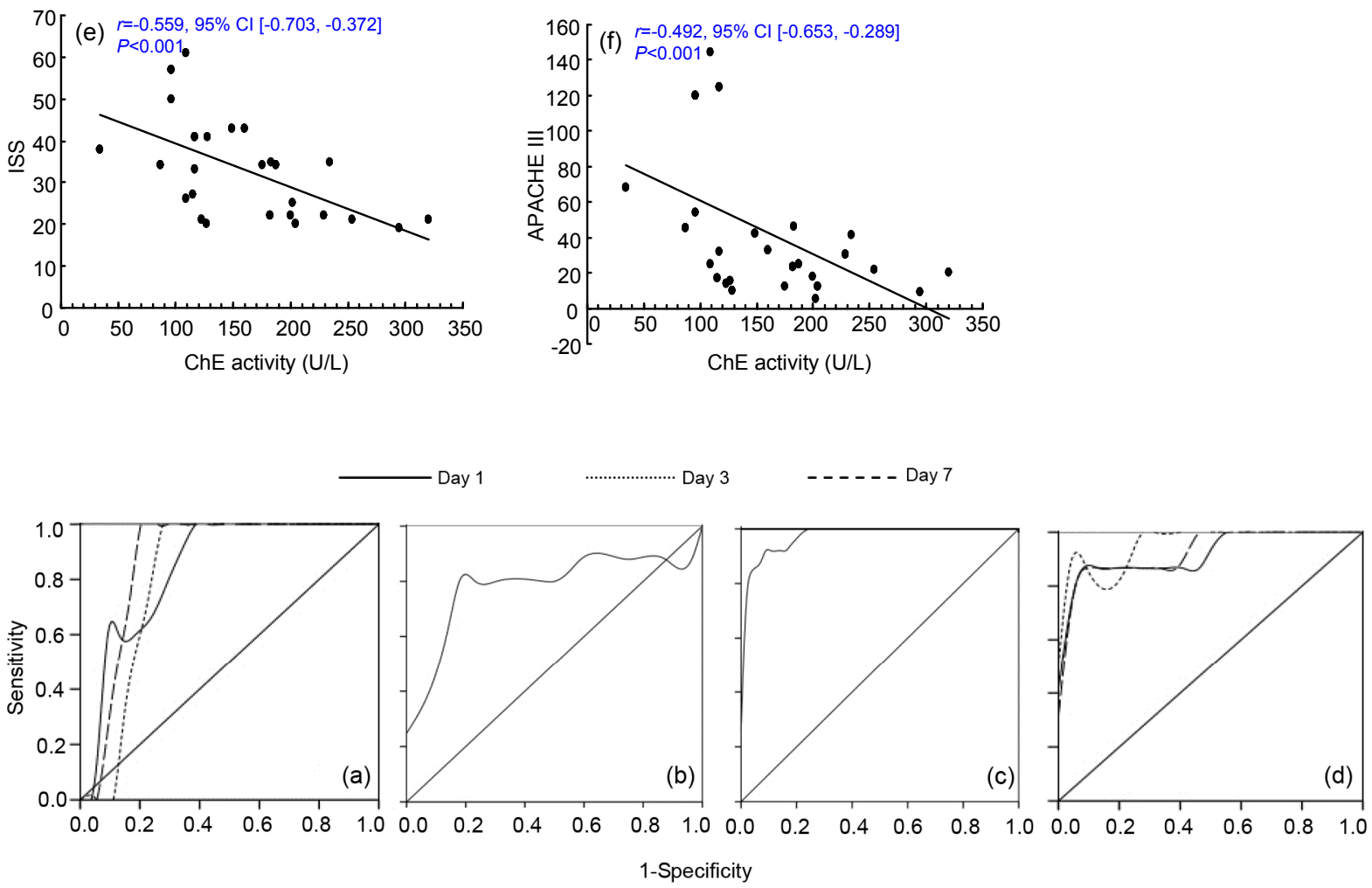

Fig. 3 ROC curves for predicting prognosis plotted with post-traumatic serum ChE (a), ISS (b), TRISS (c), and APACHE III (d) $(n=81)$

ChE: AUC $0.842 \pm 0.048$ on Day $1,0.816 \pm 0.050$ on Day 3, $0.869 \pm 0.044$ on Day $7, P<0.001$ vs. AUC $=0.5$ in all cases. ISS: AUC $0.804 \pm 0.067, P<0.001$ vs. AUC $=0.5$. TRISS: AUC $0.974 \pm 0.015, P<0.001$ vs. AUC $=0.5$. APACHE III: AUC $0.926 \pm 0.045$ on Day $1,0.967 \pm 0.024$ on Day $3,0.936 \pm 0.039$ on Day $7, P<0.001$ vs. AUC $=0.5$ in all cases 
Table 2 Analysis of optimal serum ChE threshold for predicting prognosis at different time points after severe trauma $(n=81)$

\begin{tabular}{cccccc}
\hline Time & Optimal threshold (U/L) & Sensitivity & Specificity & Youden's index & Positive likelihood ratio \\
\hline Day 1 & 197.0 & 1.000 & 0.536 & 0.536 & 2.155 \\
Day 3 & 152.5 & 0.818 & 0.732 & 0.550 & 3.052 \\
Day 7 & 120.0 & 1.000 & 0.796 & 0.796 & 4.902 \\
\hline
\end{tabular}

3.5 Correlation between serum ChE activity and APPs after injury in patients with severe trauma

The concentration of PAB and TRF decreased continuously, whereas those of ALB and CRP increased continuously, in $7 \mathrm{~d}$ after injury (Table 3).

Table 3 Dynamic changes in serum PAB, CRP, TRF, and $A L B$ in severe trauma patients in $7 \mathrm{~d}$ after injury

\begin{tabular}{ccccc}
\hline Time & $\begin{array}{c}\text { PAB } \\
(\mathrm{mg} / \mathrm{dl})\end{array}$ & $\begin{array}{c}\text { CRP } \\
(\mathrm{mg} / \mathrm{dl})\end{array}$ & $\begin{array}{c}\text { TRF } \\
(\mathrm{g} / \mathrm{L})\end{array}$ & $\begin{array}{c}\text { ALB } \\
(\mathrm{g} / \mathrm{dl})\end{array}$ \\
\hline Day 1 & $147.3 \pm 38.6$ & $64.6 \pm 35.5$ & $1.5 \pm 0.4$ & $3.1 \pm 0.8$ \\
Day 3 & $122.5 \pm 40.1$ & $111.5 \pm 82.3$ & $1.5 \pm 0.5$ & $3.4 \pm 0.5$ \\
Day 7 & $120.5 \pm 45.2$ & $107.3 \pm 86.9$ & $1.4 \pm 0.5$ & $3.6 \pm 0.6$ \\
\hline$F$ & 28.192 & 14.082 & 4.904 & 24.762 \\
$P$ & $<0.001$ & $<0.001$ & 0.009 & $<0.001$ \\
\hline
\end{tabular}

PAB: prealbumin; CRP: C-reactive protein; TRF: transferrin;

ALB: albumin. Data are presented as mean $\pm \mathrm{SD}(n=81)$

In trauma patients, serum ChE activity was significantly and positively correlated with ALB $(r=0.661, \quad P<0.001 ; \quad r=0.679, \quad P<0.001 ; \quad r=0.641$, $P<0.001$; respectively), $\mathrm{PAB}(r=0.743, P<0.001$; $r=0.592, P<0.001 ; r=0.761, P<0.001$; respectively), and TRF $(r=0.713, P<0.001 ; r=0.854, P<0.001$; $r=0.713, P<0.001$; respectively) on Days 1,3 , and 7 post-injury. Serum $\mathrm{ChE}$ activity was significantly and negatively correlated with CRP on Days 3 and 7 $(r=-0.373, P=0.001 ; r=-0.485, P<0.001$; respectively), but not on Day 1 ( $r=-0.021, P=0.857)$.

\section{Discussion}

ChE is a type of glycoprotein that is present in the body in the form of isoenzymes. $\mathrm{ChE}$ can be divided into true cholinesterase (or acetylcholinesterase, AchE) and pseudo-cholinesterase (or butyrylcholinesterase, $\mathrm{BChE}$ ) according to its specificity for catalytic substrates. Pseudo-cholinesterase accounts for about $90 \%$ of total serum ChE. The physiological function of pseudo-cholinesterase has not yet been elucidated. In clinical practice, serum ChE activity is widely used as an indicator for the diagnosis and evaluation of treatment effectiveness for organophosphate poisoning (Rehiman et al., 2008). It is also used for the assessment of liver function in patients with various chronic liver diseases (Yoshiba et al., 2002; Kaibori et al., 2008). Serum ChE activity decreases to variable degrees in patients who have suffered severe trauma, but there have been few reports on the dynamic changes occurring in serum $\mathrm{ChE}$ activity after injury and/or the clinical significance of these changes. In the present study, serum $\mathrm{ChE}$ activity was examined in 81 patients with severe trauma on Days 1, 3, and 7 after injury, to assess the clinical significance of changes in serum ChE after trauma.

Serum ChE activity was significantly lower on Days 1, 3, and 7 in trauma patients than in control group subjects. Furthermore, it continued to decrease for $7 \mathrm{~d}$ after the injury. Serum ChE activity decreased continuously for $7 \mathrm{~d}$ after injury in both the survival and death subgroups, but was significantly lower in the death subgroup on Days 1, 3, and 7 after injury. This finding is consistent with the results reported by Kamolz et al. (2002a; 2002b) on changes in serum $\mathrm{ChE}$ after burn injuries. Serum ChE activity decreased continuously for $7 \mathrm{~d}$ after injury in patients with relatively severe injuries (ISS $>25$ ). Conversely, in patients with ISS $\leq 25$, serum ChE activity decreased significantly during the early stages after injury, but then rose. The serum ChE activity of patients with an ISS of $>25$ was significantly lower on Days 1, 3, and 7 after injury than that of patients with an ISS of $\leq 25$. We also found that serum ChE activity was significantly and negatively correlated with ISS and APACHE III on Days 1, 3, and 7. The AUCs of the ROC curves for predicting prognosis, which were plotted using serum $\mathrm{ChE}$, were all significantly greater than 0.5 on Days 1, 3, and 7. The diagnostic value of using serum $\mathrm{ChE}$ activity for predicting prognosis was slightly lower than that of TRISS, but was comparable to that of ISS and APACHE III, 
according to the AUCs of their ROC curves. Thus, the dynamic changes in serum $\mathrm{ChE}$ activity after severe trauma may help to evaluate the severity of an injury and to predict prognosis. The greater the decrease in amplitude, the harder it will be to recover, suggesting a more severe injury and a poorer prognosis. The optimal thresholds for serum $\mathrm{ChE}$ for predicting prognosis on Days 1, 3, and 7 after injury were found to be 197.0, 152.5, and $120.0 \mathrm{U} / \mathrm{L}$, respectively. The diagnostic value of the optimal serum ChE threshold on Day 7 was the best, according to the positive likelihood ratio. Therefore, when serum ChE activity decreases continuously and is lower than the threshold value, particularly when activity is still lower than the optimal threshold of $120 \mathrm{U} / \mathrm{L}$ on Day 7, the condition must be taken seriously.

Non-specific inflammation occurs after severe trauma (Keel and Trentz, 2005). During this process, plasma proteins synthesized in the liver are defined as APPs when their concentrations increase or decrease by at least $25 \%$. Some APPs, such as CRP, increase in concentration and are known as positive APPs. Conversely, other APPS, such as ALB, PAB, and TRF, decrease in concentration and are known as negative APPs (Gabay and Kushner, 1999). In the current study, ALB and CRP increased continuously, while $\mathrm{PAB}$ and TRF decreased after injury, similar to serum ChE activity, though exogenous ALB was provided for the purpose of treatment. Moreover, serum $\mathrm{ChE}$ was found to be significantly and positively correlated with ALB, PAB, and TRF at all time points and significantly and negatively correlated with CRP at all time points except post-injury Day 1. Thus, it appears that changes in serum ChE activity are consistent with negative APP concentrations and the correlations between them are significant. Furthermore, since proteins are synthesized in the liver and serum $\mathrm{ChE}$ activity was reduced by more than $25 \%(42.3 \%-50.2 \%)$ on Days 1, 3, and 7, compared with normal controls, serum $\mathrm{ChE}$ fits the definition of an APP and can be regarded as a negative APP (Chiarla et al., 2011; Lampón et al., 2012).

The mechanisms that underlie the decrease in serum ChE activity after severe trauma have not yet been fully elucidated. Kamolz et al. (2002b) proposed possible mechanisms for decreasing serum $\mathrm{ChE}$ activity in burns patients, including: (1) reduced hepatic synthesis of $\mathrm{ChE}$ due to impaired liver function;
(2) hemodilution resulting from a large amount of fluid infusion during early resuscitation; (3) increased consumption of enzymes due to high catabolism induced by stress; (4) capillary leak syndrome, caused by shock, leading to increased extravascular transport of serum ChE. The mechanisms for reduced serum ChE activity after severe trauma may be similar to those above, though other factors, such as the inflammatory response (Kassab and Vijayakumar, 1995; Jin et al., 2011; Lampón et al., 2012), may play a role. During inflammation, ChE may act as a negative APP and participate in regulation of the inflammatory response.

The mechanism for the involvement of serum $\mathrm{ChE}$ in the inflammatory response may be related to the activation of the "cholinergic anti-inflammatory pathway' (Borovikova et al., 2000; Bernik et al., 2002). Acetylcholine can bind to different receptors and play different physiological roles (Paleari et al., 2008). After binding to the $\alpha 7$ nicotinic acetylcholine receptor, acetylcholine can inhibit the inflammatory mediators (i.e., the so-called 'cholinergic anti-inflammatory pathway') (Wang et al., 2003) and have an antiinflammatory effect via activation of the cholinergic system (Libert, 2003; Pavlov and Tracey, 2004; Pavlov et al., 2007). ChE is an important part of the cholinergic system since it is a hydrolase that is upstream of the neurotransmitter (Rodriguez et al., 2002; Paraoanu et al., 2007). Cholinesterase inhibitors also have anti-inflammatory effects (Hofer et al., 2008). Therefore, we speculate that acetylcholinesterase (AChE) activity decreases during the inflammatory response after trauma, in turn increasing the utilization of acetylcholine, thereby regulating inflammation. However, the main limitation of our study is that we did not test true cholinesterase (AChE), even though it has more specificity for acetylcholine than serum $\mathrm{ChE}$, and then seek to determine the relationship between AchE and serum ChE activity. Also, we did not test the inflammatory factors directly and could not demonstrate that the reduction of serum $\mathrm{ChE}$ was correlated with inflammatory response. The mechanism of the inflammatory response that inhibits the activity of AChE and serum $\mathrm{ChE}$ is similar to that involved in organophosphorus poisoning. Further studies should be conducted to demonstrate that the activity of serum $\mathrm{ChE}$ is correlated with AChE activity, and to clarify the role of $\mathrm{ChE}$ in the inflammatory 
response. In this study, the dynamic changes in serum ChE were correlated with the severity of injury in trauma patients. Dynamic measurements of serum ChE could be used as a simple and repeatable auxiliary index for patient monitoring and predicting prognosis during the acute phase of trauma. Moreover, serum ChE may be a new biomarker or regulatory factor for the inflammatory response if future studies can confirm and clarify its role (Santarpia et al., 2013).

\section{Conclusions}

In summary, serum $\mathrm{ChE}$ activity decreases significantly after injury in patients with severe trauma. A greater decrease appears to indicate a more severe injury and a poorer prognosis. Serum ChE activity after trauma was well correlated with APP concentration and may be regarded as a type of negative APP.

\section{Compliance with ethics guidelines}

Li BA, Ding-qian WU, An-yu QIAN, Mao ZHANG, and Bing XIONG declare that they have no conflict of interest.

All procedures followed were in accordance with the ethical standards of the responsible committee on human experimentation (institutional and national) and with the Helsinki Declaration of 1975, as revised in 2008 (5). Informed consent was obtained from all patients for being included in the study.

\section{References}

Bernik, T.R., Friedman, S.G., Ochani, M., et al., 2002. Pharmacological stimulation of the cholinergic antiinflammatory pathway. J. Exp. Med., 195(6):781-788. [doi:10. 1084/jem.20011714]

Borovikova, L.V., Ivanova, S., Zhang, M., et al., 2000. Vagus nerve stimulation attenuates the systemic inflammatory response to endotoxin. Nature, 405(6785):458-462. [doi: $10.1038 / 35013070]$

Chiarla, C., Giovannini, I., Giuliante, F., et al., 2011. Plasma cholinesterase correlations in acute surgical and critical illness. Minerva Chir., 66(4):323-327.

Chougule, A., Hussain, S., Agarwal, D.P., 2008. Prognostic and diagnostic value of serum pseudocholinesterase, serum aspartate transaminase, and serum alinine transaminase in malignancies treated by radiotherapy. J. Cancer Res. Ther., 4(1):21-25. [doi:10.4103/0973-1482.39601]

Cowan, J.A.Jr., Dubosh, N., Hadley, C., 2009. Seatbelt and helmet depiction on the big screen blockbuster injury prevention messages. J. Trauma Inj. Infect. Crit. Care,
66(3):912-917. [doi:10.1097/TA.0b013e318166d740]

Evans, J.A., van Wessem, K.J., Mcdougall, D., et al., 2010. Epidemiology of traumatic deaths: comprehensive population-based assessment. World J. Surg., 34(1):158163. [doi:10.1007/s00268-009-0266-1]

Gabay, C., Kushner, I., 1999. Acute-phase proteins and other systemic responses to inflammation. N. Engl. J. Med., 340(6):448-454. [doi:10.1056/NEJM199902113400607]

Hofer, S., Eisenbach, C., Lukic, I.K., et al., 2008. Pharmacologic cholinesterase inhibition improves survival in experimental sepsis. Crit. Care Med., 36(2):404-408. [doi:10.1097/01.CCM.0B013E31816208B3]

Jin, Q.H., He, X.J., Li, T.L., et al., 2011. Predictive value of serum cholinesterase for the prognosis of aged patients with systemic inflammatory response syndrome. Chin. Med. J., 124(17):2692-2695 (in Chinese). [doi:10.3760/ cma.j.issn.0366-6999.2011.17.023]

Kaibori, M., Matsui, K., Saito, T., et al., 2008. Risk factors for early death due to recurrence after resection of large hepatocellular carcinomas. Hepatogastroenterology, 55(88):2151-2156.

Kamolz, L.P., Andel, H., Greher, M., et al., 2002a. Serum cholinesterase activity in patients with burns. Clin. Chem. Lab. Med., 40(1):60-64. [doi:10.1515/CCLM.2002.012]

Kamolz, L.P., Andel, H., Greher, M., et al., 2002b. Serum cholinesterase activity reflects morbidity in burned patients. Burns, 28(2):147-150. [doi:10.1016/S0305-4179 (01)00091-2]

Kassab, A.S., Vijayakumar, E., 1995. Profile of serum cholinesterase in systemic sepsis syndrome (septic shock) in intensive care unit patients. Eur. J. Clin. Chem. Clin. Biochem., 33(1):11-14.

Keel, M., Trentz, O., 2005. Pathophysiology of polytrauma. Injury, 36(6):691-709. [doi:10.1016/j.injury.2004. 12.037]

Lampón, N., Hermida-Cadahia, E.F., Riveiro, A., et al., 2012. Association between butyrylcholinesterase activity and low-grade systemic inflammation. Ann. Hepatol., 11(3): 356-363.

Libert, C., 2003. Inflammation: a nervous connection. Nature, 421(6921):328-329. [doi:10.1038/421328a]

Lo, W.K., 2006. Serum parameters, inflammation, renal function and patient outcome. In: Ronco, C., Dell'Aquila, R., Rodighiero, M.P. (Eds.), Peritoneal Dialysis: A Clinical Update. Contrib Nephrol, Basel, Karger, Vol.150, p.152-155. [doi:10.1159/000093515]

Murdock, D., 2008. Trauma: when there's no time to count. AORN J., 87(2):322-328. [doi:10.1016/j.aorn.2007.07. 008]

Nzegwu, M.A., Banjo, A.A., Akhiwu, W., et al., 2008. Morbidity and mortality among road users in Benin-City, Nigeria. Ann. Afr. Med., 7(3):102-106. [doi:10.4103/ 1596-3519.55669]

Paleari, L., Grozio, A., Cesario, A., et al., 2008. The cholinergic system and cancer. Semin. Cancer Biol., 18(3): 211-217. [doi:10.1016/j.semcancer.2007.12.009] 
Paraoanu, L.E., Steinert, G., Koehler, A., et al., 2007. Expression and possible functions of the cholinergic system in a murine embryonic stem cell line. Life Sci., 80(24-25):2375-2379. [doi:10.1016/j.lfs.2007.03.008]

Pavlov, V.A., Tracey, K.J., 2004. Neural regulators of innate immune responses and inflammation. Cell. Mol. Life Sci., 61(18):2322-2331. [doi:10.1007/s00018-004-4102-3]

Pavlov, V.A., Ochani, M., Yang, L.H., et al., 2007. Selective $\alpha 7$-nicotinic acetylcholine receptor agonist GTS-21 improves survival in murine endotoxemia and severe sepsis. Crit. Care Med., 35(4):1139-1144. [doi:10.1097/01.CCM. 0000259381.56526.96]

Rehiman, S., Lohani, S.P., Bhattarai, M.C., 2008. Correlation of serum cholinesterase level, clinical score at presentation and severity of organophosphorous poisoning. $J$. Nepal. Med. Assoc., 47(170):47-52.
Rodriguez, J.A., Buzaleh, A.M., Fossati, M., et al., 2002. The effects of some porphyrinogenic drugs on the brain cholinergic system. Cell. Mol. Biol., 48(1):103-110.

Santarpia, L., Grandone, I., Contaldo, F., et al., 2013. Butyrylcholinesterase as a prognostic marker: a review of the literature. J. Cachexia Sarcopenia Muscle, 4(1):31-39. [doi:10.1007/s13539-012-0083-5]

Wang, H., Yu, M., Ochani, M., et al., 2003. Nicotinic acetylcholine receptor $\alpha 7$ subunit is an essential regulator of inflammation. Nature, 421(6921):384-388. [doi:10.1038/ nature01339]

Yoshiba, M., Sekiyama, K., Inoue, K., et al., 2002. Accurate prediction of fulminant hepatic failure in severe acute viral hepatitis: multicenter study. J. Gastroenterol., 37(11):916-921. [doi:10.1007/s005350200154]

\section{中文概要：}

\section{本文题目: 严重创伤后血清胆碱酯酶活性的动态变化}

Dynamic changes of serum cholinesterase activity after severe trauma

研究目的：探讨严重创伤患者早期血清胆碱酯酶（ChE）活性的动态变化规律与临床意义。

创新要点: 阐明了在严重创伤后早期血清 $\mathrm{ChE}$ 动态的变化规律, 为评估创伤的严重程度和预后判断提 供新的参考辅助指标。

研究方法: 前瞻性观察研究: 分析 81 例严重创伤患者伤后第 $1 、 3 、 7$ 天血清 $\mathrm{ChE}$ 活性的动态变化, 通 过亚组 (不同预后、不同伤情严重程度) 间变化比较及与损伤严重度评分 (ISS)、急性生理 和慢性健康评分 III (APACHE III) 和创伤严重程度评分（TRISS）进行比较, 评估其反映 病情严重程度和预后的价值; 同时分析伤后血清 ChE 活性与急性期蛋白（APP）, 如白蛋白 ( ALB)、前白蛋白 (PAB)、转铁蛋白 ( TRF) 和 C 反应蛋白 (CRP) 浓度变化的关系。

重要结论: 血清 $\mathrm{ChE}$ 活性在严重创伤后显著降低, 持续下降的幅度越大, 则提示损伤越重, 预后可能 越差, 而且血清 $\mathrm{ChE}$ 或可视为负急性期蛋白的一种, 血清 $\mathrm{ChE}$ 作为严重创伤伤情和预后评 估的简单辅助指标具有一定的可靠性。

关键词组: 多发性创伤; 血清胆碱酯酶; 急性期蛋白 